\title{
Role of signal-averaged electrocardiography and ventricular late potentials in patients with chronic obstructive pulmonary disease
}

\author{
C.A. BUZEA ${ }^{1,2}$, G.A. DAN ${ }^{1,2}$, ANCA RODICA DAN ${ }^{2}$, CATERINA DELCEA ${ }^{2}$, \\ M.I. BALEA ${ }^{2}$, DANIELA STEFANA GOLOGANU ${ }^{2}$, MIHAELA DOBRANICI ${ }^{1,2}$, \\ RALUCA ALEXANDRA POPESCU ${ }^{1,2}$ \\ "“Carol Davila" University of Medicine and Pharmacy, 37 Dionisie Lupu, \\ Bucharest, District 1, 020022 Romania \\ ${ }^{2}$ Colentina Clinical Hospital, 19-22 Ştefan cel Mare, Bucharest, District 2, 020125, Romania
}

\begin{abstract}
Patients with chronic obstructive pulmonary disease (COPD) have an increased risk for cardiac arrhythmias. Ventricular late potentials (VLP) on signal-averaged electrocardiography (SAECG) are associated with an increased risk for malignant ventricular arrhythmias. Our aim is to investigate the modifications of SAECG parameters and the presence of VLP as possible indicators of proarrhythmic substrate in patients with COPD. We prospectively enrolled 41 consecutive patients in the COPD group and 63 patients without any history of pulmonary disease, matched for age and hypertension history, in the control group. Pulmonary function tests, arterial blood gases, echocardiography, 24-hour Holter monitoring and SAECG were performed. We measured total filtered QRS duration (QRSf), duration of high frequency, low-amplitude signals $<40 \mathrm{~V}$ (HFLA40), and root mean square voltage in the last $40 \mathrm{~ms}$ (RMS40). VLP were considered if at least two of these parameters were abnormal.

Results. We did not register any significant differences in QRSf, HFLA40 or RMS40 between the two groups. In the COPD group there was a non-significant higher percentage of patients with VLP in comparison with the control group. In the COPD patients we registered a significantly higher number of isolated premature ventricular beats and of combined complex ventricular arrhythmias, consisting of polymorphic PVC, couplets, triplets or nonsustained ventricular tachycardias. None of these arrhythmic parameters correlated with SAECG variables or with the presence of VLP.

Conclusion. In COPD patients parameters measured on signal-averaged electrocardiography and ventricular late potentials analysis have little value in risk stratification for ventricular arrhythmias.
\end{abstract}

Keywords: COPD, chronic obstructive pulmonary disease, arrhythmias, late potential, signalaveraged electrocardiography.

\section{INTRODUCTION}

Patients with chronic obstructive pulmonary disease (COPD) have an increased risk for cardiac arrhythmias and even sudden cardiac death [1-3]. The presence of ventricular late potentials (VLP) on signal-averaged electrocardiography (SAECG) is associated with an increased risk for malignant ventricular arrhythmias [4,5]. Ventricular late potentials are high-frequency, low-amplitude signals in the terminal portion of the QRS complex indicating a delayed activation of the myocardium that may suggest the presence of a reentry predisposing substrate $[6,7]$. There are scarce data about the role of VLP in patients with COPD. Our aim is to investigate the modifications of SAECG parameters and the presence of VLP as possible indicators of proarrhythmic substrate in patients with COPD.

\section{MATERIALS AND METHODS}

\section{STUDY POPULATION}

We included 42 patients ( 29 males, mean age $61 \pm 9$ years) diagnosed with COPD according to the Global Initiative for Chronic Obstructive Lung Disease (GOLD) criteria [8] and 62 patients without any history of pulmonary disease (26 males, mean age $58 \pm 13$ years) in the control group, matched for age and hypertension history. We excluded patients with history or signs of ischemic heart disease, with history of myocardial revascularization or cardiac surgery, significant valvular disease, known atrial fibrillation or other chronic arrhythmias, heart failure or left ventricular ejection fraction (LVEF) $<50 \%$, known thyroid dysfunction, permanent bundle block, antiarrhythmic treatments or permanent implantable devices. All patients signed a written 
informed consent form. The study protocol was approved by our institution Ethics Committee. The study population was prospectively included between June 2014 and January 2015 from a single hospital center.

\section{PROCEDURES}

\section{Pulmonary function tests}

Pulmonary function testing was performed using a Vitalograph Alpha 6000 spirometer (Vitalograph, Ireland) for all patients with COPD. Forced vital capacity (FVC) and forced expiratory volume in the first second (FEV1) were measured in milliliters and expressed as percentages of the predicted values established by the European Community Respiratory Health Survey.

\section{Arterial blood gases}

Samples for the arterial blood gases were obtained from the radial artery in all patients with COPD while breathing room air. $\mathrm{pH}, \mathrm{pO}_{2}, \mathrm{pCO}_{2}$ and $\mathrm{HCO}_{3}$ results were recorded. Also, the oxygen saturation by pulse oximetry was analyzed in all patients.

\section{Echocardiography}

The echocardiographic examination was performed with an iE33 xMATRIX (Philips, The Netherlands) system with 2,5-3,5 MHz transducers. $\mathrm{M}$-mode and 2D-dimensional measurements were done in all standard windows, according to the recommendations of the European Society of Echocardiography. The left ventricular ejection fraction (LVEF) was calculated using Simpson's biplane method and pulmonary artery pressure (PAP) was calculated using the modified Bernoulli equation: $\mathrm{PAP}=4 \times(\text { tricuspid systolic jet })^{2}+10 \mathrm{~mm} \mathrm{Hg}$.

\section{Holter Recordings}

Twenty-four hour ambulatory ECG recordings were obtained with a CardioMem ${ }^{\circledR}$ CM 3000 (GE Healthcare, Germany) system. The recordings were downloaded to a CardioDay Holter software (GE Healthcare, Germany). These were reviewed by a cardiology specialist to confirm 18 hours of clear recording, and the beat classifications were manually checked and corrected. The recordings were screened for ventricular arrhythmias defined as isolated premature ventricular beats (PVC), couplets or triplets, bigeminy or ventricular tachycardias (VT).
We defined VT as 4 or more consecutive ventricular impulses.

\section{Signal-averaged electrocardiography}

SAECG was performed in all patients using a MAC 5500HD (GE Healthcare, Germany) system. We measured total filtered QRS duration (QRSf), duration of high frequency, low-amplitude signals $<40 \mathrm{~V}$ (HFLA40), and root mean square voltage in the last $40 \mathrm{~ms}$ (RMS40). Values of QRSf $>114 \mathrm{~ms}$, HFLA40 $>38 \mu \mathrm{ms}$ and RMS40 $<20 \mu \mathrm{V}$ were considered abnormal and VLP were positive when at least two of these criteria were present [7]. The values were recorded when a noise level $<1 \mu \mathrm{V}$ was obtained, by averaging $\geq 250$ beats.

\section{Statistical analysis}

Statistical analysis was performed with NCSS 10 Statistical Software (NCSS, LLC. Kaysville, Utah, USA) and Medcalc 15.2 (MedCalc Software, Ostend, Belgium). The normality was tested with D'Agostino-Pearson and Komolgorov-Smirnov tests. Descriptive statistics values were given as mean \pm standard deviation and percentage ratios. The comparison between two groups was made using chi-squared test or Fisher's exact test as appropriate. The numeric variables were correlated using MannWhitney test. The $\mathrm{p}$ values $<0.05$ were considered statistically significant.

\section{RESULTS}

In our study there were no significant differences in age or history of arterial hypertension between the patients with COPD and the control group, but there was a significantly higher incidence of diabetes and of both history and active smoking among COPD patients. On clinical examination, patients with COPD had higher BMI, respiratory and heart rates and lower oxygen saturation, with no differences in systolic or diastolic blood pressures (Table 1).

The pulmonary function tests and arterial gases analysis in patients with COPD are shown in Table 2.

We observed significantly higher right atrial and right ventricular diameters as well as increased pulmonary arterial pressure in COPD patients in comparison with controls. Also, these patients had a marginally higher incidence of LV hypertrophy (Table 3). 
Table 1

General characteristics

\begin{tabular}{|l|c|c|c|}
\hline & COPD $(\mathrm{N}=42)$ & Control $(\mathrm{N}=62)$ & p-value \\
\hline \multicolumn{2}{|c|}{ Demographics and cardiovascular risk } \\
\hline Age, $\mathrm{y}$ & $61 \pm 8.8$ & $58 \pm 13.5$ & 0.2 \\
\hline Male gender, N & $29(69 \%)$ & $26(31 \%)$ & 0.009 \\
\hline BMI, kg/m ${ }^{2}$ & $31.5 \pm 8.9$ & $28.1 \pm 3.9$ & 0.3 \\
\hline History of smoking, N & $32(86.5 \%)$ & $3(8.1 \%)$ & $<0.0001$ \\
\hline Active smoking, N & $18(43.9 \%)$ & $1(1.6 \%)$ & $<0.0001$ \\
\hline Arterial hypertension, N & $23(56 \%)$ & $16(47 \%)$ & 0.49 \\
\hline Diabetes mellitus, N & $10(24 \%)$ & $3(5 \%)$ & 0.005 \\
\hline & Clinical examination \\
\hline Systolic blood pressure, $\mathrm{mmHg}$ & $133.8 \pm 23.5$ & $131.3 \pm 16.2$ & 0.9 \\
\hline Diastolic blood pressure, $\mathrm{mmHg}$ & $79.2 \pm 16.2$ & $80 \pm 10$ & 0.57 \\
\hline Heart rate, bpm & $84.4 \pm 17$ & $73.6 \pm 15$ & 0.004 \\
\hline Respiratory rate, rpm & $26 \pm 7$ & $17 \pm 1.3$ & $<0.0001$ \\
\hline Oxygen saturation, \% & $88 \pm 7$ & $98 \pm 1.1$ & $<0.0001$ \\
\hline
\end{tabular}

Table 2

Pulmonary function tests and blood gases analysis in COPD patients $(\mathrm{N}=42)$

\begin{tabular}{|l|c|}
\hline \multicolumn{1}{|c|}{ Parameter } & Value \\
\hline $\mathrm{FVC}, \%$ & $63 \pm 22$ \\
\hline $\mathrm{FEV}_{1}, \%$ & $42 \pm 15$ \\
\hline $\mathrm{FEV}_{1} / \mathrm{FVC}, \%$ & $55 \pm 14$ \\
\hline $\mathrm{pH}$ & $7.4 \pm 0.1$ \\
\hline $\mathrm{pO}_{2}, \mathrm{mmHg}$ & $59 \pm 9$ \\
\hline $\mathrm{pCO}_{2}, \mathrm{mmHg}$ & $48 \pm 12$ \\
\hline $\mathrm{HCO}_{3}, \mathrm{mmol} / \mathrm{L}$ & $28 \pm 7$ \\
\hline \multicolumn{2}{|l|}{ FEV1 - forced expiratory volume in the first second; $\mathrm{FVC}$ - forced vital capacity. }
\end{tabular}

Table 3

Echocardiographic measurements

\begin{tabular}{|l|c|c|c|}
\hline & COPD $(\mathrm{N}=42)$ & Control $(\mathrm{N}=62)$ & p-value \\
\hline LA, mm & $36.8 \pm 6$ & $34.5 \pm 5$ & 0.07 \\
\hline LVIDd, mm & $47.6 \pm 5$ & $47.8 \pm 5.3$ & 0.8 \\
\hline LVISd, mm & $34.4 \pm 5$ & $33.5 \pm 6$ & 0.46 \\
\hline IVSd, mm & $12.2 \pm 2$ & $11.2 \pm 2$ & 0.051 \\
\hline LVPWd, mm & $11.1 \pm 2$ & $10.7 \pm 2$ & 0.047 \\
\hline RA, mm & $37 \pm 5$ & $33.5 \pm 5$ & 0.007 \\
\hline RV, mm & $30.5 \pm 5$ & $27 \pm 3$ & $<0.001$ \\
\hline PAP, mmHg & $32 \pm 13$ & $21 \pm 10$ & 0.003 \\
\hline LVEF, $\%$ & $56 \pm 7$ & $58 \pm 4$ & 0.07 \\
\hline
\end{tabular}

IVSd - interventricular septum diastolic diameter; LVPWd - left ventricular posterior wall diastolic diameter; LVIDd - left ventricular internal diastolic diameter; LVISd - left ventricular internal diastolic diameter; $L V E F$ - left ventricular ejection fraction; $L A$ - left atrium; $R A$ - right atrium; $R V$ - right ventricle; $L V$ - left ventricle; PAP - systolic pulmonary artery pressure.

On SAECG analysis, we did not register any significant differences in the COPD group compared to the control group regarding QRSf $(122 \pm 31 \mathrm{~ms} v s .112 \pm 14.8 \mathrm{~ms}, \mathrm{p}=0.18)$, HFLA40 $(40 \pm 34 \mathrm{~ms} v s .34 \pm 13, \mathrm{p}=0,4)$ or RMS40 $(35 \pm$
$21 \mu \mathrm{V}$ vs. $40 \pm 19 \mu \mathrm{V}, \mathrm{p}=0.27)$. Regarding the presence of VLP, there was a higher percentage of patients who met at least two of the three criteria in the COPD group, but without reaching statistical significance (Table 4). 
Table 4

Presence of late ventricular potentials

\begin{tabular}{|c|c|c|c|}
\hline & $\operatorname{COPD}(\mathrm{N}=42)$ & Control $(\mathrm{N}=62)$ & p-value \\
\hline \multicolumn{4}{|l|}{ Abnormal parameters } \\
\hline QRSf $>114 \mathrm{~ms}, \%$ & 38 & 31 & 0.52 \\
\hline $\mathrm{HFLA}_{40}>38 \mathrm{~ms}, \%$ & 24 & 24 & 1 \\
\hline $\mathrm{RMS}_{40}<20 \mu \mathrm{V}, \%$ & 26 & 13 & 0.12 \\
\hline \multicolumn{4}{|c|}{ VLP } \\
\hline Two criteria, \% & 26 & 19 & 0.47 \\
\hline Three criteria, $\%$ & 19 & 10 & 0.24 \\
\hline
\end{tabular}

QRSf - total filtered QRS duration, HFLA40 - duration of high frequency, low-amplitude signals $<40 \mathrm{~V}, \mathrm{RMS} 40$ - root mean square voltage in the last $40 \mathrm{~ms}$.

In the COPD group, compared to controls, we registered a significantly higher number of PVC ( $704 \pm 2112$ vs. $340 \pm 1138, \mathrm{p}=0.0002$ ) (Figure 1) and a non-significant higher percentage of patients with combined complex ventricular arrhythmias, consisting of polymorphic PVC, couplets, triplets or nonsustained ventricular tachycardias $(50 \%$ vs. $32 \%$ patients, $\mathrm{p}=0.1$ ) (Figure 2).

However, none of these arrhythmic parameters correlated either with any SAECG variables or with the presence of VLP defined by two criteria $(\mathrm{z}=0.26, \mathrm{p}=0.8$ for PVC and $\mathrm{t}(17)=0.34, \mathrm{p}=0.78$ for complex ventricular arrhythmias) or three criteria $(\mathrm{z}=0.21, \mathrm{p}=0.8$ for PVC and $\mathrm{t}(10)=0.76, \mathrm{p}=0.46$ for complex ventricular arrhythmias) in the COPD group. Moreover, in this subgroup analysis the presence of VLP was not correlated with any echocardiographic, pulmonary function tests or blood gases parameters. Interestingly, both PVC and complex ventricular arrhythmias were not correlated with pulmonary function tests or blood gases analysis.

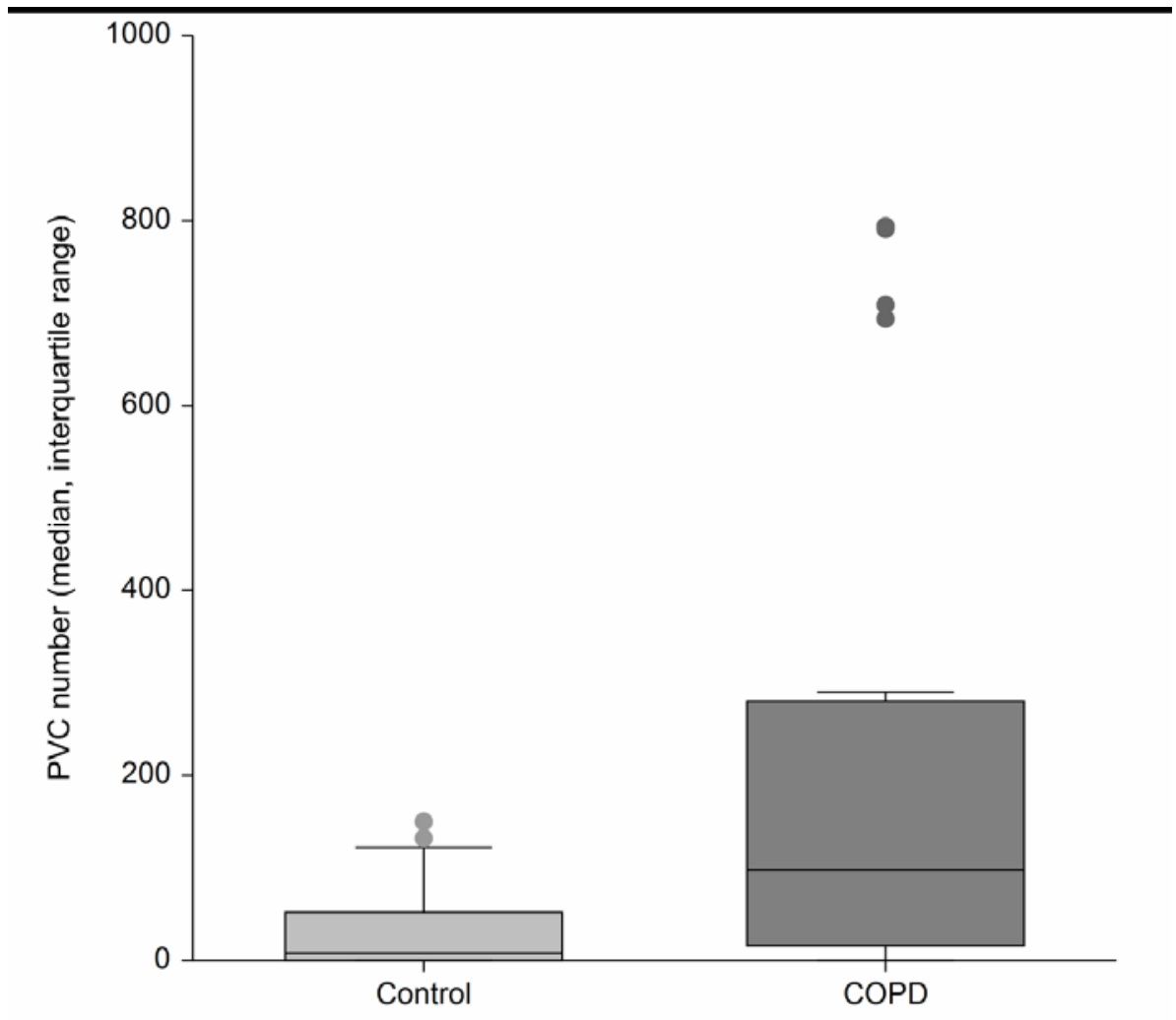

Fig. 1. PVC number in COPD and control groups ( $\mathrm{p}=0.002$, Mann Whitney U test). 


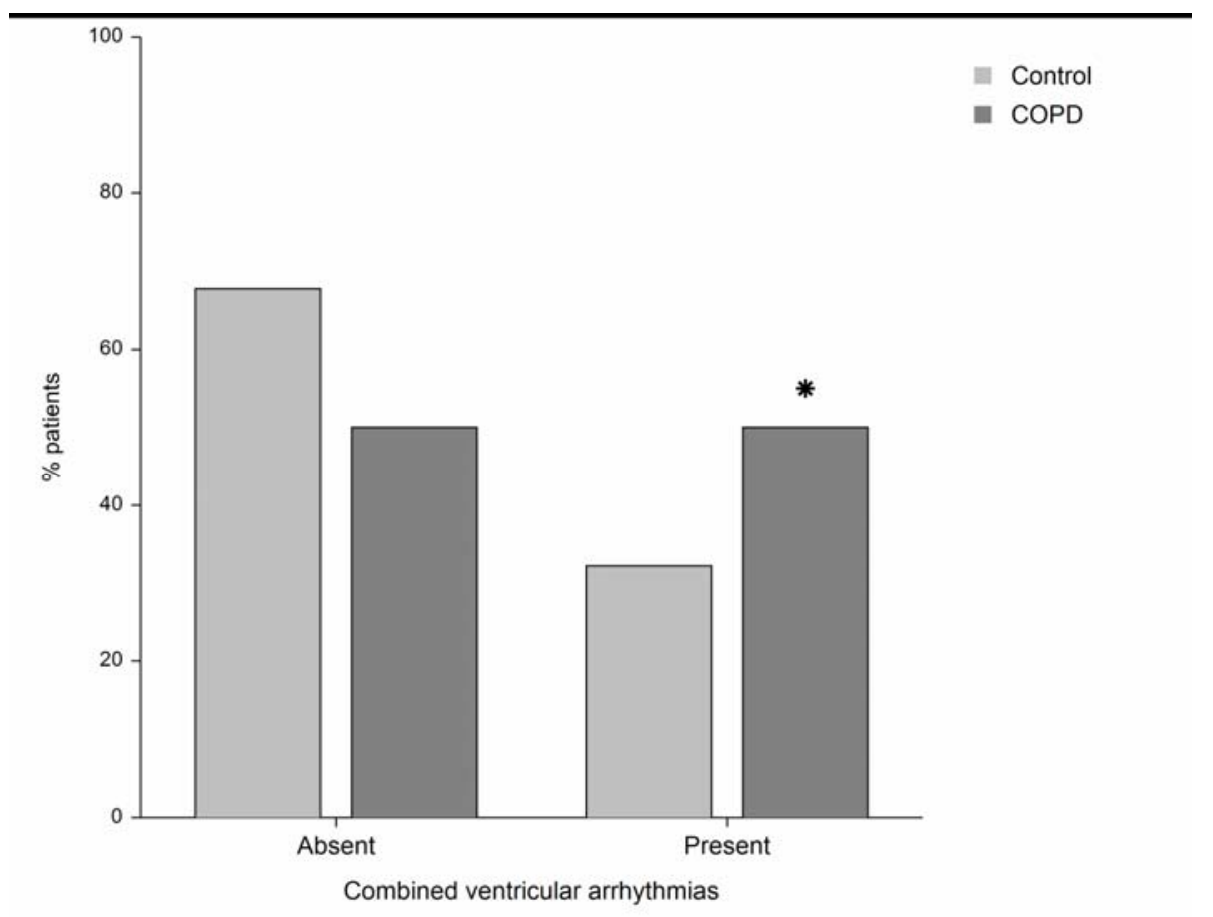

Fig. 2. Incidence of complex ventricular arrhythmias ( $\mathrm{p}=0.1 \mathrm{vs}$. control).

\section{DISCUSSION}

In COPD patients ventricular arrhythmias and sudden cardiac death are important causes of mortality and many factors may contribute to their development like blood gas alterations or acid-base disturbances [9-12]. Despite this, we have scarce evidence regarding the usefulness of different parameters for identifying those at higher risk of arrhythmias. We aimed to verify the utility of SAECG parameters and the presence of VLP in COPD patients.

Our study did not find any significant differences in QRSf, HFLA40 and RMS40 parameters between COPD patients and the control group. Furthermore, despite the higher presence of VLP in the COPD subgroup, defined by at least two criteria according to the current guidelines [4,7], the difference did not achieve statistical significance. COPD patients had a higher incidence of isolated PVC and of complex ventricular arrhythmias compared to the control group, but none of these was correlated with SAECG parameters. The presence or absence of VLP failed to show any utility in depicting those COPD patients with higher incidence of complex ventricular arrhythmias, with an AUC of 0.47, a positive predictive value of $45 \%$ and a negative predictive value of $47 \%$ if defined by two criteria and an AUC of 0.47 , a positive predictive value of $37.5 \%$ and a negative predictive value of $54.5 \%$ if defined by three criteria. In the COPD subgroup analysis the presence of VLP was not correlated with pulmonary respiratory parameters or arterial blood gas analysis. There is scarce data regarding SAECG analysis in COPD patients. However, in a trial published in 2002, Yildiz et al. [13] did not find any difference in terms of SAECG parameters and VLP in a group of 30 patients with COPD compared to healthy subjects. They also registered a higher incidence of PVC and VT in COPD subgroup, but not correlated to SAECG parameters. In comparison to this trial, in our study the population had a higher number of patients in both subgroups. Also, we included patients with hypertension and diabetes. In terms of severity of COPD both trials were comparable regarding pulmonary function tests and blood gases analysis.

\section{LIMITATIONS}

This is a single-center, open study with a relatively low number of cases. Presumably a larger, randomized cohort is necessary to add more definite evidence to the role of SAECG analysis in COPD patients. 


\section{CONCLUSIONS}

In COPD patients parameters measured on signal-averaged electrocardiography and ventricular late potentials analysis have little value in risk stratification for ventricular arrhythmias.

Acknowledgements

We thank Marian Miricioiu who was responsible for the technical aspects of Holter monitoring and SAECG.

Pacienții cu boală pulmonară obstructivă cronică (BPOC) au risc crescut pentru aritmii cardiace. Potentialele tardive ventriculare (PTV) din electrocardiografia cu mediere de semnal (SAECG) se asociază cu un risc mare pentru aritmii ventriculare maligne. Scopul nostru este de a investiga modificările parametrilor SAECG şi prezența PTV ca posibili indicatori ai substratului proaritmic la pacienții cu BPOC. Au fost înrolați consecutiv 41 de pacienți în grupul BPOC şi 63 pacienți în grupul de control fără niciun istoric de boală pulmonară, fiind comparabili din punctul de vedere al vârstei şi istoricului de hipertensiune arterială. Au fost efectuate teste funcționale pulmonare, dozarea gazelor arteriale, ecocardiografie, monitorizare Holter de 24 ore şi SAECG. Am măsurat durata totală a QRS filtrat (QRSf), durata semnalelor de frecvență inaltă şi amplitudine mică < 40V (HFLA40) şi rădăcina pătrată medie în ultimele $40 \mathrm{~ms}$ (RMS40). Au fost considerate PTV dacă cel puțin doi din aceşti parametri au fost anormali.

Rezultate. Nu am observat diferențe semnificative între cele două grupuri în ceea ce priveşte QRSf, HFLA40 şi RMS40. Procentul de pacienți cu PTV a fost nesemnificativ mai mare în grupul BPOC față de grupul de control. La pacienții din grupul BPOC am înregistrat un număr semnificativ mai mare de extrasistole ventriculare izolate şi de aritmii ventriculare complexe constând în extrasistole ventriculare polimorfe, cuplete, triplete sau tahicardie ventriculară nesusținută. Niciunul din acești parametri aritmici nu s-a corelat cu variabilele SAECG sau cu prezența PTV.

Concluzie. La pacienții cu BPOC parametrii măsurați cu electrocardiografia cu mediere de semnal şi analiza potențialelor tardive ventriculare au o valoare mică pentru stratificarea riscului pentru aritmii ventriculare.

Corresponding author: Cătălin Adrian Buzea

19-22 Ştefan cel Mare, Bucharest, District 2, 020125, Romania Phone: +40 745771745

Email: adrian_c_buzea@yahoo.com

\section{Grant support}

This paper is supported by the Sectorial Operational Programme Human Resources Development (SOP HRD), financed from the European Social Fund and by the Romanian Government under the contract number POSDRU/159/1.5/S/137390.

Conflicts of interest: none.

\section{REFERENCES}

1. FUSO L, INCALZI RA, PISTELLI R, MUZZOLON R, VALENTE S, PAGLIARI G, et al. Predicting mortality of patients hospitalized for acutely exacerbated chronic obstructive pulmonary disease. Am. J. Med. 1995; 98:272-7.

2. HOLFORD FD, MITHOEFER JC. Cardiac arrhythmias in hospitalized patients with chronic obstructive pulmonary disease. Am. Rev. Respir. Dis. 1973;108:879-85.

3. SIN DD, MAN SFP. Chronic obstructive pulmonary disease as a risk factor for cardiovascular morbidity and mortality. Proc. Am. Thorac. Soc. 2005;2:8-11.

4. STEINBERG JS, BERBARI EJ. The signal-averaged electrocardiogram: update on clinical applications. J. Cardiovasc. Electrophysiol. 1996;7:972-88. 
5. IKEDA T, SAKATA T, TAKAMI M, KONDO N, TEZUKA N, NAKAE T, et al. Combined assessment of T-wave alternans and late potentials used to predict arrhythmic events after myocardial infarction. A prospective study. J. Am. Coll. Cardiol. 2000;35:722-30.

6. SIMSON MB, UNTEREKER WJ, SPIELMAN SR, HOROWITZ LN, MARCUS NH, FALCONE RA, et al. Relation between late potentials on the body surface and directly recorded fragmented electrograms in patients with ventricular tachycardia. Am. J. Cardiol.1983;51:105-12.

7. BREITHARDT G, CAIN ME, EL-SHERIF N, FLOWERS NC, HOMBACH V, JANSE M, et al. Standards for analysis of ventricular late potentials using high-resolution or signal-averaged electrocardiography: A statement by a task force committee of the European Society of Cardiology, the American Heart Association, and the American College of Cardiology. J. Am. Coll. Cardiol.; 1991;17:999-1006.

8. RABE KF, HURD S, ANZUETO A, BARNES PJ, BUIST SA, CALVERLEY P, et al. Global strategy for the diagnosis, management, and prevention of chronic obstructive pulmonary disease: GOLD executive summary. Am. J. Respir. Crit. Care Med. 2007;176:532-55.

9. THEOFILOGIANNAKOS EK, ANOGEIANAKI A, TSEKOURA P, GLOUFTSIOS P, ILONIDIS G, HATZITOLIOS A, et al. Arrhythmogenesis in patients with stable chronic obstructive pulmonary disease. J. Cardiovasc. Med. (Hagerstown). 2008 ;9:89-93.

10. INCALZI RA, PISTELLI R, FUSO L, COCCHI A, BONETTI MG, GIORDANO A. Cardiac arrhythmias and left ventricular function in respiratory failure from chronic obstructive pulmonary disease. Chest 1990;97:1092-7.

11. ROGERS RM, SPEAR JF, MOORE EN, HOROWITZ LH, SONNE JE. Vulnerability of canine ventricle to fibrillation during hypoxia and respiratory acidosis. Chest 1973;63:986-94.

12. HUDSON LD, KURT TL, PETTY TL, GENTON E. Arrhythmias associated with acute respiratory failure in patients with chronic airway obstruction. Chest 1973;63:661-5.

13. YILDIZ P, TÜKEK T, AKKAYA V, SÖZEN AB, YILDIZ A, KORKUT F, et al. Ventricular arrhythmias in patients with COPD are associated with QT dispersion. Chest 2002;122:2055-61. 